\title{
HET MA'BOEA EN DE TATOUAGE IN SEKO, (MIDDEN-CELEBES).
}

(Met 2 Platen).

DOOR J. KR ס T.

Het landschap Seko ligt in de onderafdeeling Masamba van de afdeeling Loewoe, diep in het westelijk binnenland van Midden-Celebes. Wanneer men van het landschap Rongkong in het $Z$. O. komt en het hooge scheidingsgebergte overtrekt, en later het landschapje verlaat langs den weg naar het landschap Rampi in het N.O., dan krijgt men een levendigen indruk van de afgeslotenheid van Seko. Hoewel men weet te vertellen van vele invallen van vijanden in vroeger tijden, zoowel van het noorden als van het zuiden en westen, kunnen wij toch, gezien de terreinsgesteldheid, veilig aannemen, dat Seko steeds een vrijwel afgesloten gebied is geweest. De afsluiting van een volk kan echter nooit absoluut opgevat worden, omdat de mensch beweeglijker is dan iets anders op het aardoppervlak en zelfs door zeer groote moeilijkheden van berg en water niet tegengehouden kan worden op zijn tochten. Zoo moeten de Sekoërs sterke invloeden van Rampi hebben ondergaan. Maar wanneer men het met andere streken vergelijkt, moet men zeggen: Seko is een afgesloten land.

Het landschap kan men in twee duidelijk van elkaar gescheiden deelen verdeelen, nl. Seko Pada in de Oosthelft, een langwerpige, zuidoost-noordwest verloopende vlakte en in de Westhelft het dal van de Betoewe, dat hier oost-west loopt. In het eerste gedeelte liggen de dorpen Lodang(Z.) en Wono (N.), in het tweede Amballong (O.) en Pewaneang(W. $)^{1}$ Van deze plaatsen moet Lodang de jongste zijn, want de bevolking is samengesteld uit afstammelingen van menschen van Amballong en Wono.

"Zie blad 3 van de "Schetskaart van Midden-Celebes door Alb. C. KROYT", $1: 200.000$ (zonder plaats of jaar; maar verschenen te Batavia, Topogr. Inrichting, 1915!. [RED.].

Dl. 76 
In dit land $n u$ is nog een laatste overblijfsel te vinden van tatouage. Omdat deze kunst bezig is geheel uit te sterven, en omdat er omtrent den aard der tatouage in het algemeen nog 200 weinig zekerheid bestaat, besloot ik op den tocht, dien Dr. A. C. Kruyt en ik in dit jaar (1919) door het westelijk deel van Midden-Celebes maakten, zooveel mogelijk gegevens omtrent deze tatouage te verzamelen. Bij het onderzoek bleek echter, dat dit gebruik in nauw verband staat met het haliangschap, en dit op zijn beurt weer met het ma'boea, een feest, dat gevierd wordt om de levenskrachten van mensch, buffel en rijst te versterken. Zoo ben ik ertoe gekomen om alle gegevens omtrent het ma'boea en de tatouage in één geheel samen te vatten. Hieronder zal $i k$ dus eerst een en ander omtrent het ma'boea mededeelen, om vervolgens tot de tatouage over te gaan.

\section{Het MA'Boea.}

Er bestaat een aanmerkelijk verschil tusschen de wijze, waarop men te Pewaneang en Amballong gewend was de boea te vieren en die, waarop de lieden van Wono hem hielden en nog houden. Wij zullen eerst nagaan, hoe het feest te Pewaneang verliep. Ik zeg "verliep», omdat de plechtigheden in optima forma niet meer plaats kunnen hebben, daar er toch een menschenoffer voor noodig was. Hier komt dus alleen ter sprake, wat men eertijds gewend was te doen.

Wanneer de rijst eenige malen achtereen mislukt is, wanneer er veel sterfte is onder de buffels, of wanneer de menschen veel te kampen hebben met ziekte en dood, besluit men een boea te vieren. Is het nu den tijd om de nieuwe tuinen en sawahs te beplanten, dan zegt men tot de geesten (d e hata): "Wanneer ge de rijst goed doet gelukken, zullen we ma'boea. " Na den eerstvolgenden oogst lost men deze belofte in.

Is de tijd -daartoe aangebroken, dat is dus, nadat men de nieuwe rijst heeft binnen gehaald, dan gaat een groep mannen erop uit om in een "ver land, een mensch te koopen. Van koppensnellen is geen sprake, men gaat met eenige buffels als betaalmiddel een slaaf halen. Een bepaalde streek, vanwaar men gewoon was een slachtoffer te betrekken, had men niet: men ging zoeken, en waar men er een krijgen kon, sloeg men zijn slag. De laatste keer kocht men een To Mapo', die aan de 
bronnen der Lasa in Galoempang wonen. Gewoonlijk was één voldoende, hetzij man of vrouw, die men dan met twee buffels betaalde. Voor zulk een slachtoffer zochten de verkoopers een ouden slaaf of eene slavin uit, die toch weinig meer waard was.

Wanneer de uitgezondenen met hun koop dicht bij hun dorp gekomen zijn, laten zij hun dorpsgenooten weten, dat ze den volgenden dag hun woonplaats zullen bereiken. Dadelijk is dan het geheele dorp in beweging. Den volgenden dag slacht men voor ieder gezin een kip en kookt men groote hoeveelheden rijst. Hierop gaat men de terugkeerenden tegemoet, zeggende, dat ze hun buffel gaan zien. Hierbij neemt men de klaar gemaakte spijzen mee. Buiten het dorp eet men gezamenlijk, waarop allen met het meegebrachte slachtoffer in het dorp gaan. Deze gekochte slaaf of slavin heet tandasang. Men zeide ons uitdrukkelijk, dat voor tandasang uitsluitend een vreemde kon gebruikt worden, en wel een uit een ver verwijderd land; bovendien mocht hij (of zij) nooit tevoren in Seko geweest zijn.

Zijn allen in het dorp teruggekeerd, dan worden de haliangs aangewezen. Onder de To Seko heeft men drie standen: de tobara', die de edelen vormen, de todirenge, de gewone vrije burgerman, en de kaoenan, welke laatsten gekochte slaven van Rongkong zijn. Wanneer in dit opstel sprake is van 'de tobara',, dan wordt hiermede het familie-hoofd der tobara'-stand bedoeld, die tevens hoofd van het dorp of den stam is. De tobara' nu wijst uit zijn familie drie jonge vrouwen aan, die haliang zullen worden. Getrouwde vrouwen komen voor haliang niet in aanmerking, evenmin als leden van den todirengeof kaoenan-stand. Zijn de haliangs aangewezen, dan gaan dezen naar den tandasang en raken hem (of haar) aan, terwijl ze hem vriendelijk toespreken en zeggen, dat hij niet bang moet zijn, want dat men goed voor hem zal zorgen. Hierop gaat de tandasang in het huis van den tobara', op den voet gevolgd door de drie haliangs, die van dit oogenblik af aan alle verbodsbepalingen van het haliangschap verbonden zijn. Op deze verbodsbepalingen komen wij hieronder terug, wanneer we de boea van Wono bespreken. Tegelijkertijd dat de tandasang in het huis van den tobara' klimt, drijft men drie buffels onder hetzelfde huis in een afgezette ruimte.

Den volgenden dag heeft het ma'paroe plaats, d. i. het offeren aan de geesten. Ten oosten van het huis van den tobara' 
heeft men op het erf een plek, die heilig is. Om de plaats aan te duiden heeft men er eenige steenen neergelegd zonder eenige regelmaat in de rangschikking te betrachten. Bij navraag verklaarde men uitdrukkelijk, dat de steenen zelf niets beteekenen, dat men deze naar believen kan verwisselen met andere willekeurige steenen, maar dat dit stukje grond heilig is. Hier nu heeft het ma'paroe plaats, waarbij men een ei, gestampte rijst en palmwijn offert.

Dan verlaten alle mannen en vrouwen gezamenlijk het huis van den tobara' en gaan op het erf zingen (monghota). Alleen de tandasang en de haliangs nemen geen deel aan deze zangen, maar moeten in huis blijven. Vier of vijf vrouwen, de z.g. poponghota, spelen een bijzondere rol bij deze zangen: onder het zingen houden zij gezamenlijk een jong blad van de konaoe (Arenga saccharifera) vast.

Zijn de zangen ( $p \circ n g h \circ t a)$ afgeloopen, dan gaat men over tot de plechtigheid, die popasodang heet. Een man, de posodang geheeten, staat beneden op den grond aan den voet der trap van het tobara'-huis; een tweede man, die men potoeak noemt, staat boven aan die trap. De posodang neemt nu het konaoe-blad, waarmede de poponghota de zangen hebben uitgevoerd, en steekt het den potoeak drie malen toe. Eerst bij de derde maal grijpt deze het blad en brengt het in huis. Hierop volgen de poponghota naar binnen. Laatstgenoemden zetten zich nu kalm neer en kauwen sirihpinang. Wanneer zij hiermede klaar zijn, staan de poponghota op en nemen gezamenlijk het $k$ on a o e-blad in de hand, heffen het driemaal op en laten het dan op den vloer vallen. Hierop gaan alle vier (of viif) met de voeten het blad betreden. Vervolgens nemen zij het weer op en scheuren met de nagels de bladschijf van de zijnerven los, waardoor men een franje van het soepele, jonge blad krijgt. Het geheel wordt in de lengte in tweeën gedeeld, door de hoofdnerf te splijten.

Tevoren heeft men reeds in huis een paroeng gebouwd. Dit is een offertafel van bamboe, die ongeveer een meter hoog is en waarvan het blad, dat uit bamboelatten bestaat, ongeveer een meter in het vierkant zal zijn. Vanaf de paroeng heeft men verder nog een ladder gemaakt, die naar het dak leidt. Is het konaoe-blad bewerkt zooals hierboven beschreven is, dan klimmen de pongkaloe (over wien beneden meer), de 
potoeak en de posodang langs genoemde ladder naar boven, waarbij zij pinang en Dracaena terminalis meenemen. Een van de helften van het k o n a o e-blad wordt hun drie malen toegestoken. Eerst bij de derde maal grijpen zij het en binden het aan de ladder vast, waarop zij de meegenomen Dracaena terminalis en pinang aan het opperste einde van dit halve blad vasthechten. De andere helft van het k ona oe-blad wordt aan stukken gesneden en op verschillende plaatsen in het huis opgehangen. Vooral het dak wordt hiermede versierd.

Den volgenden dag (den derden van het feest) worden de drie buffels, die men op den eersten dag onder het huis heeft gebracht, geslacht. Hiertoe worden ze alle drie aan de middenpaal van het huis, de petoeko, vastgebonden. Een man, de pongkaloe geheeten, bindt zich in het huis van den tobara' de huid van een buidelrat (cuscus) op den rug en neemt een mandje (t e mpoeroeng) met gestampte rijst in de hand. Zoo toegerust daalt hij uit het huis af en loopt drie malen van links naar rechts om de buffels heen, terwijl hij ze met gestampte rijst bestrooit. Hierop gaat hij weer naar binnen en slaat drie malen op den trom. Terwijl hij dit doet, slacht men de buffels onder het huis. Dan gaat de pongkaloe weer naar beneden en roept bij de gedoode dieren de geesten aan. Vervolgens klimt hij weer in huis en legt zijn cuscus-huid af op de paroeng.

De geslachte buffels worden nu aan stukken gesneden. Het vleesch mag alleen in dit huis, d.i. dus in het huis van den to bara', bereid worden. Maar overigens is men hierbij aan geen bepalingen gebonden; men mag het b. v. in de gebruikelijke aarden potten koken. Wanneer het vleesch gaar is, offert de tobara' een klein gedeelte ervan op de paroeng, waarop ieder van de spijs eten mag.

Intusschen hebben de haliangs steeds in het huis van den to ba ra' gezeten, zonder dat zij aan iets een werkzaam aandeel hebben genomen. Op den vierden dag wordt echter een einde gemaakt aan hun haliangschap. Hiertoe worden zij uit het huis gedragen en onder aan de trap neergezet. Hier overgiet men haar met water uit bamboe-kokers (ze worden (gebaad»), waarop zij weer over den grond (de aarde) mogen loopen, hetgeen der haliang verboden was. Want zoodra de baad-plechtigheid volvoerd is, is er een einde gemaakt aan het haliangschap, en vervallen dus alle verbodsbepalingen, die aan dezen staat ver- 
bonden zijn. $\mathrm{Na}$ de water-ceremonie loopen de gewezen haliangs naar. een der rijstschuren, die uitgekozen is als plaats, waar de tatouage uitgevoerd zal worden. Deze drie ex-haliangs zijn verplicht zich te laten tatoueeren, $Z_{\mathrm{ijn}}$ zij gereed, dan mag ieder, die wil, zich ook aan deze bewerking onderwerpen. Op deze tatouage komen wij beneden uitvoerig terug.

Op den vijfden dag kookt men a mbelong bladeren; van het aftreksel ervan moet iedereen drinken als teeken, dat de feestelijkheden afgeloopen zijn. Den zesden dag gaan allen brandhout halen, en op den zevenden dag begint men met de landbouwwerkzaamheden. De eene helft van het gezin gaat een drogen tuin openen, de andere helft zet zich aan de bewerking der natte velden.

Intusschen leeft de tandasang nog, en wordt zelfs heel goed verzorgd en vriendelijk behandeld. Want wanneer het met de rijst, de menschen en de buffels goed blijft gaan, maakt men eerst na drie jaar een eind aan de boea. Blijft de rijst echter niet gelukken en is er veel sterfte en ziekte onder mensch en dier, dan besluit men na twee jaar reeds de boea te sluiten. Gedurende dezen wachttijd heeft de tandasang een goed leven, en doet licht werk voor zijn heeren.

Is de tijd van het beëindigen der boe a aangebroken, dan gaat men den eersten dag gezamenlijk naar een willekeurigen berg buiten het dorp om er het ma'patong uit te voeren. Men neemt gekookte rijst en voor elk gezin één kip mee. Deze laatste worden geslacht, waarop men aan de dehata te eten geeft. Daartoe plant men een stengel van de sierbamboe (Mal. bamboe tjina) in den grond en geeft er op zekere hoogte van den grond een inkeeping in. Hierin klemt men de volgende offergave vast: een masapi-blad (Pewaneang: petape, Lodang: pami'oehai, Wono: pedoi) en een pisangblad, waarbij men zorgt, dat de stelen dezer bladeren naar het oosten wijzen; hierop legt men dan nog wat kippenvleesch, kippenlever, gekookte rijst en een ei. Wanneer allen op deze plek gegeten hebben, keert men weer naar huis terug.

Den tweeden dag gaat men er opuit om de buffels op te vangen, die men slachten wil. Uit den aard der zaak is de tijd, die hiermede verstrijkt, zeer verschillend. Het aantal der buffels is willekeurig, hoe grootscher men het feest maken wil, hoe meer dieren er geslacht worden. Wanneer nu het afgesproken aantal 
er is, steekt men 's avonds op het erf voor het huis van den tobara' een groot vuur aan. Hier omheen voert men drie avonden achtereen dansen uit met zang (menani). De voorganger bij deze zangen, de popenani, hanteert een echte lans (doke belo), terwijl de overige mannen hun dansen met lansen van bamboe (doke talang) uitvoeren. Bovendien hebben de mannen zich nog met songko gala getooid, een muts van apenvel of gevlochten rotan, waarop twee koperen hoorns zijn bevestigd.

$\mathrm{Na}$ den derden nacht waarin men het menanie heeft uitgevoerd, daalt 's morgens, vòòr het nog begint te lichten (zoo ongeveer vier uur), de pongkaloe uit het huis van den tobara' af. Hij heeft wederom den cuscushuid op den rug gebonden en een mandje met gestampte rijst in de hand. Ditmaal wordt hij gevolgd door vrouwen, die zich op haar mooist hebben aangekleed. De pongkaloe bestrooit de buffels, die geslacht zullen worden, met de gestampte rijst en gaat dan weer in huis, op den voet gevolgd door de vrouwen. Hierop worden de buffels geslacht en tegelijkertijd de tandasang gebonden.

Wanneer het feestmaal gereed is eten allen, en ook de tandasang wordt roijaal bedeeld. Omdat hij reeds gebonden is en dus zichzelf niet kan helpen, wordt hij door anderen gevoerd. $\mathrm{Na}$ den maaltijd leidt men den tandasang naar buiten en stoot hem met het hoofd op de foeja-klopplank van den tobara'. Dan neemt een ander hem, brengt hem naar zijn huis en stoot met zijn hoofd tegen zijn rijstblok aan. Zoo wordt hij rond gesleept en met zijn hoofd tegen rijstblok of klopplank gestooten, terwijl men hem onder de bedrijven door nog voedsel in den mond stopt. Op deze wijze half doud gemarteld, wordt de tandasang ten slotte naar het huis van den tobara' teruggeleid. Hier plaatst men hem boven op het portaal zittende bij de trap. Alle mannen staan beneden gewapend met stokken. De tobara' spreekt nu den tandasang aldus toe: 'Reken het mij niet tot fout aan, dat ik een mensch dood. Ik ben ook een mensch als gij, maar ik heb u met mijn buffels gekocht.» Dan trekt hij den tandasang aan zijn beenen naar beneden, waar hij, op den grond gevallen, met vereende krachten doodgeslagen wordt. Hierop sleept men hem tot vóbr het huis van den tobara, waar de vrouwen nog eens met stokken op het. lijk slaan.

De pongkaloe snijdt hem nu het hoofd af, waarop het lichaam ten westen van het huis van den tobara' met de 
beenen naar boven begraven wordt. Het hoofd wordt zoolang boven een vuur geroosterd, totdat het schoon is, d.w.z. de weeke deelen verdwenen zijn of gemakkelijk verwijderd kunnen worden. Is dit gereed, dan hangt men dit hoofd samen met de horens der geslachte buffels in het huis van den tobara' aan den middenpaal, den petoeho. Hierop klimt de pongkalo'e naar boven om boven de buffelhorens aan de dehata het volgende te offeren: gekookte rijst, lever van een buffel en een ei. Daarna breekt men de paroeng (offertafel) af.

Den volgenden dag neemt de pongkaloe de oude schedels, nl. die van de tandasangs, die bij de vorige gelegenheden gedood zijn, van hun plaats weg. Onderwijl houden de mannen op het erf spiegelgevechten met de stengels van rietgras (Seko: tariang). De pongkaloe brengt nu de schedels op een berg in de nabijheid van het dorp. Hier legt hij hen op den grond, offert aan de dehata en brengt dan deze schedels weer op hun plaats in het huis van den tobara' terug. Dit heet het ma'palapa boea: het sluiten van de boea.

Gaan wij nu over tot de beschrijving der gewoonten bij de boe a der inwoners van Wono, dan zien wij, dat ook daar het feest gevierd wordt, wanneer de rijst niet gelukken wil, en onder mensch en dier veel ziekte en sterfte voorkomt. Heeft men tot het houden van een boe a besloten, dan gaat men eerst in het huis van den tobara' de paroeng (offertafel) met de bijbehoorende ladder bouwen, zooals dit te Pewaneang en Amballong geschiedt. Boven de paroeng brengt men een cirkelvormigen hoepel aan, die horizontaal wordt opgehangen en met rotans aan het dak vastgebonden is. Aan dezen hoepel heeft men franjes van jong kona oe-blad bevestigd. Dit toestel heet toeloena tami: de versiering van het huis. Verder wordt uitgemaakt, wie haliang zullen worden. Dit beteekent voor de uitverkorenen te Wono heel wat meer dan voor haar zusters te Pawaneang en Amballong. Want terwijl op laatstgenoemde plaatsen het haliangschap slechts drie dagen duurt, zijn de haliangs van Wonu zoolang in functie, totdat de boea gesloten is, wat tot drie jaren toe kan duren. In tegenstelling met Pewaneang en Amballong is men geheel vrij in het bepalen van het aantal haliangs. Bovendien kan men haar zoowel uit den tobara'-als uit den todirenge-stand nemen. De kaoenan, die vreemdelingen zijn, komen natuurlijk niet in aanmerking. 
Het is hier de plaats een en ander omtrent de verbodsbepalingen der haliangs mede te deelen. Alleen ongehuwden mogen haliang worden en gedurende dien tijd mogen zij geen geslachtsgemeenschap hebben. $\mathrm{Zij}$ moeten zooveel mogelijk in huis blijven. In het huis van den tobara' zijn er altijd eenigen, maar wanneer er veel zijn, wonen $z i j$ ook wel in andere huizen van het dorp. Voor vreemdelingen moeten zij zich steeds verborgen houden. Wanneer zij buitenshuis komen, bedekken zij zich geheel met een saroeng. $Z_{\mathrm{ij}}$ mogen niet geraakt worden door regen noch beschenen door de zonnestralen. Zich te baden is verboden, daarom wrijven $z i j$ zich in met rijstemeel, vermengd met een beetje water (dit meel heet te Lodang en Amballong: parimanti, te Wono: ponte). Haar werk bestaat in rijst stampen, matten vlechten ${ }^{1}$ en ander licht werk. Ten einde haar onder het stampen, dat onder het huis dicht bij de trap gedaan wordt, tegen de blikken van het publiek te beschermen, heeft men met gevlochten bamboe deze plaatsen afgeschoten, zoodat de haliangs een kamer hebben, waarin zij dit werk verrichten. Te Wono, waar men bij ons bezoek haliangs had, zagen wij bij twee huizen zulke kamertjes. Bovendien deelde men ons te Lodang nog mede, dat de volgende spijzen voor de haliangs verboden zijn: colocasia (Seko: kale se), de gewone oebi (Seko: kanoa), een eetbaar varenkruid dat in het Bare'e pakoe ge. noemd wordt (Seko: tampaoe), het vleesch van den Anoa depressicornis (Seko: tokata), maîs (Seko: bata) en een klein soort visch, ansang genaamd.

Wanneer men de boea opent, brengt men op den eersten dag een buffel onder het huis van den tobara', waar het dier aan een paal wordt vastgebonden. Tegelijkertijd gaan de haliangs in het huis, en worden van dit oogenblik af alle verbodsbepalingen voor haar van kracht. Op een tweeden dag gaat men een jong k on a o e-blad halen. Den derden dag wordt dit blad bewerkt als te Pewaneang en Amballong, waarbij de buffel onder het huis geslacht wordt.

Op den vierden dag heeft het mantamo haliang plaats. Een buffel wordt buiten het dorp losgelaten; de mannen maken nu zoolang jacht op het dier, totdat men erin geslaagd is het

\footnotetext{
1 In Seko is men zeer bedreven in het vlechten van mooie matjes; ongetwijfeld heeft het Instituut der haliangs tot de ontwikkeling dezer kunst bijgedragen, daar toch deze jonge vrouwen veel tijd aan dit werk kunnen besteden.
} 
te dooden. Het vleesch met den afgehakten kop wordt naar het huis van den tobara' gebracht, waar het vleesch toebereid en gegeten wordt. Wanneer het avond geworden is, legt men den buffelkop ten westen van de paroeng op den vloer. Al de haliangs stappen nu beurt om beurt eerst op den kop, bestijgen van daar de paroeng, en dalen aan den oostkant weer af. De vrouwen zingen dezen nacht in het tobara'-huis, waarbij men op trommels slaat (dit zingen heet doemono). Den volgenden dag gaat men de sawahs openen, maar eenige nachten zetten de vrouwen het doemono voort.

Blijft alles goed gaan, gelukken de sawahs, zijn de menschen en de buffels gezond, dan sluit de boea eerst na drie jaren. Heeft men echter met tegenslag te kampen, dan eerder. Veronderstellen wij, dat alles voorspoedig gaat, en de boea dus eerst na drie jaar beëindigd wordt. Wanneer dan de eerste oogst na het begin der boea achter den rug is, worden alle handelingen uitgevoerd, die ook bij de opening der boea plaats hadden. Eén uitzondering is er echter: in plaats dat men jacht maakt op een losgelaten buffel, slacht men er een op de gewone wijze. Voor de ceremonie, waarbij de haliangs op een buffelkop stappen ten westen van de paroeng om over deze heen aan de oostzijde weer af te dalen, gebruikt men den kop van dezen buffel. Bij dit feest worden aan de haliangs van het vorige jaar eenigen toegevoegd, die dus een jaar korter in functie zijn dan haar zusters, maar die gedurende haar haliangschap aan precies dezelfde verbodsbepalingen gebonden zijn. De versieringen van jong ko na o e-blad aan het dak en aan de toeloena tami worden vernieuwd (mangkaholai), of eigenlijk voegt men aan die van het vorige jaar nieuwe toe.

Den volgenden (vierden) dag heeft het masohang tampo plaats, waarbij alle mannen en vrouwen, die er aan deelnemen, en met uitzondering van de haliangs, uit het huis van den tobara' afdalen en op het erf zangen uitvoeren, begeleid met trommelslag (maleha). Dit doet men overdag; wanneer het ongeveer vier uur in den namiddag is geworden, gaan allen weer in het huis, waar het maleha wordt voortgezet. Den volgenden dag gaat men dan weer de nieuwe sawahs openen.

Het volgende jaar na den oogst, het tweede dus na het begin der boea, doet men gelijk als het voorgaande jaar. Ook deze keer worden weer eenige nieuwe haliangs aan die van de twee vorige malen toegevoegd. 
Wanneer de derde oogst na het begin der boea achter den rug is, wordt de boe a gesloten. Het eerste, wat men nu doet, is het neerhalen van de toeloena tami, de hoepelvormige versiering boven de paroeng. Dan gaan de mannen er op uit om de benoodigde buffels op te vangen. Zoo mogelijk moet er voor iedere haliang één buffel zijn. Maar kan de familie dit niet bekostigen, dan kunnen twee of drie haliangs ook te zamen met één buffel volstaan. Bovendien heeft men voor varkens te zorgen, en wel voor iedere haliang één varken. Met het opvangen der buffels gaat een geruimen tijd heen, en zoolang blijft de toeloena tami neergelaten.

$Z_{\text {ijn }}$ de benoodigde dieren bijeen, dan kunnen de feestelijkheden beginnen. Op den eersten dag wordt een eind aan het haliangschap gemaakt. Daartoe worden de varkens (zooveel varkens als er haliangs zijn) gebonden en ten westen van het tobara'huis op een rij gelegd. Deze rij verloopt noord-zuid, terwijl de koppen der dieren naar het oosten liggen. Dan dalen de haliangs, voorgegaan door den poleha, een man, uit het huis van den tobara' af. Ieder van hen heeft een mandje met gestampte rijst in de hand. De poleha met de haliangs loopen nu acht maal om het huis van links naar. rechts; telkens, wanneer zij bij de rij varkens gekomen zijn, stappen zij op elk van die dieren, ze tegelijkertijd met gestampte rijs bestrooiend. Wanneer deze acht ommegangen gedaan zijn, is er een eind gekomen aan het haliangschap en zijn alle daaraan verbonden verbodsbepalingen vervallen. De varkens worden nu geslacht en in een ten oosten van het huis opgerichte hut gelegd.

Op den tweeden dag worden de buffels onder het huis geleid en daar gebonden. De gewezen haliangs maken wederom acht ommegangen om het huis, waarbij zij de buffels met gestampte rijst bestrooien. Hierop gaan vier mannen, posakoe geheeten, onder het huis en dooden de buffels met speren. De schachten dezer lansen mogen geen der huispalen raken, want dan zou het gewas niet gelukken. Gebeurt het toch, dat een der mannen tegen een huispaal stoot, dan wordt de dader gestraft met een boete in gestampte rijst en eieren, $Z$ ijn de buffels op deze wijze afgemaakt, dan daalt de tobara' uit zijn huis af en wendt groote verstoordheid voor, terwijl hij zegt: "Wie doodt hier mijn buffels; als ik den dader te pakken krijg, zal ik hem zeker dooden., Hierop gaat hij weer naar binnen. Het vleesch dezer dieren wordt 
nu in de hut ten oosten van het huis, waar den vorigen dag de varkens geborgen waren, gebracht. Van al dit vleesch richt men nu een feestmaal aan. Nadat de tobara' een gedeelte ervan op de paroeng aan de dehata geofferd heeft, doet ieder zich tegoed aan de spijzen. Het genoemde offer heet pararoek.

Dezen dag begint ook een eigenaardig gebruik, nl. het schommelen (mempio). Onder het huis van den tobara brengt men eenige schommels van rotan aan. De gewezen haliangs moeten allen eerst schommelen; hierna mag ieder, die wil, ook meedoen. Vier dagen schommelt men. $\mathrm{Na}$ deze vier schommeldagen wordt een buffel geslacht: masoesoeng toeloena geheeten. Aan den toeloena tami, die men van nieuwe franjes heeft voorzien, offert men van het vleesch van dezen buffel. Daarna wordt hij weer op zijn oude plaats gehangen.

Den volgenden dag heeft het masangki'i plaats, dat niet anders is dan een opruiming. De rotan schommels onder het huis worden weggenomen, en de paroeng breekt men af. Alleen de "versieringen" in het huis laat men zitten. Zoo zagen wij aan het dak van den tobara'. te Wono tallooze, zwart berookte bladreepen hangen. Ook de toeloena tami wordt niet verwijderd. Men zegt, dat er geen geesten in wonen; ook geeft het niets, wanneer hij door een lek in het dak natregent. Maar toch is hij een belangrijk voorwerp, want bij elke boea wordt hij opnieuw versierd, en wanneer men in een ander huis trekt, gaat de toeloena tami mee.

Den hierop volgenden dag slacht men een onbepaald aantal kippen, het z.g. masalee. Van het vleesch offert men op de heilige plek ten oosten van het huis van den tobara'. Wanneer dit gedaan is, mag men de landbouwwerkzaamheden weer beginnen. $Z$ ijn de zaailingen van de padi ongeveer 15 dagen oud, dan heeft het moriri plaats. Hierbij slacht men eenige kippen en varkens, offert een gedeelte op dezelfde plek als bij het masalee, en eet gezamenlijk het overige gedeelte op.

Eerst na den volgenden oogst heeft de tatouage plaats. Bij die gelegenheid slacht men dan een buffel. Evenals te Pewaneang en Amballong zijn ook te Wono de gewezen haliangs verplicht zich te laten tatoueeren, waarna ieder ander zich vrijwillig aan de bewerking mag onderwerpen. Terwijl echter de kunstbewerking te Pewaneang en Amballong bij éen keer afgeloopen is, verloopen bij de To Wono twee jaren, voordat de tatouage voltooid is. De eerste 
keer worden alleen de onderarmen bewerkt; dan wacht men een vol jaar, om na den volgenden oogst eerst bovenarmen en schouders hun beurt te geven. Ook hierbij slacht men weer een buffel.

Voordat wij van het ma'boea afstappen, moet nog een legende vermeld worden omtrent den oorsprong van dit gebruik. Op onze vraag, van wie zij het $\mathrm{ma}$ 'bo a geleerd hadden, vertelde men ons te Wono het volgende: In vroeger tijd was er iemand te Wono, die een zoon had. Deze zoon spaarde hij veel te veel: de jongen zat altijd maar thuis en voerde niets uit. Toen kwam er een geest, die zijn woning in het water had (de rivier nl.). en deze zeide: 'Op deze wijze moogt ge uw zoon niet liefhebben; alleen een dochter moogt ge aldus liefhebben, maar dan moet er een feest bij zijn. Hierop nam de geest den zoon mee naar zijn woning in het water, en gaf hem zijn dochter ten huwelijk. Twee jaren bleef hij bij dezen geest wonen, in welken tijd hij het $\mathrm{ma}$ 'boea bijwoonde en de gebruiken daarbij leerde. $\mathrm{Na}$ afloop van deze boea keerde hij naar Wono terug, vergezeld van zijn vrouw, die mensch geworden was. Van deze twee heeft men het ma'boea geleerd. Men weet echter van geen dezer personen den naam op te geven.

\section{De Tatouage.}

In de beschrijving van het ma'boea hebben wij een antwoord gevonden op de vraag, wie getatoueerd worden. Wij hebben gezien, dat de haliangs, die ongetrouwd moeten zijn, getatoueerd moeten worden, terwijl bij deze gelegenheid ieder ander, man en vrouw, zich aan de kunstbewerking mag onderwerpen. Aan een bepaalden leeftijd is men niet gebonden, zoodat degene, die zich wil laten bewerken, zich alleen de vraag te stellen heeft: «Durf ik de pijn aan ? Z Zoo ja, dan verhindert niets hem of haar zich te laten tatoueeren.

Gaan wij nu na, wie tatoueert. Bij gelegenheid van iedere tatouage moet er een leider zijn, die poronno heet (moronno: tatoueeren; ronno: de figuren, de tatouage) ${ }^{1}$ Deze poronno is

1 De reden, waarom wij dit woord met een dubbele $n$ spellen, is om aan te duiden, dat deze klank met eene eigenaardige spanning wordt uitgesproken. De tong wordt krachtiger en iets langer tegen bet verhemelte gedrukt, dan dit bij de uitspraak der gewone $n$ het geval is. Deze verdubbeling der $n$ in de spelling slaat dus niet op de uitspraak van de voorafgaande klinker, maar heeft betrekking op de uitspraak van de $n$ zelf. 
altijd een man; hij moet afstammen van een familie, die altijd deze kunstenaars heeft voortgebracht, m.a.w. het is erfelijk gebonden aan een bepaalde familie. Alleen bij de tatouage treedt hij op, maar overigens onderscheidt hij zich in niets van zijn dorpsgenooten, noch is hij aan eenige bijzondere verbodsbepalingen gebonden.

Gaat men echter tatoueeren, dan is hij de leider. Hij legt de tijdens de bewerking geldende verbodsbepalingen op (waarover beneden meer). Aan deze bepalingen is de poronno zelf ook onderworpen. $\mathrm{Hij}$ tatoueeert, maar omdat hij het werk niet alleen af kan, mag hij door anderen geholpen worden. Zoowel mannen als vrouwen mogen helpen tatoueeren; het eenige vereischte is, dat ze de figuren goed kennen en er geen fouten in maken. Het spreekt wel vanzelf, dat de helpers en helpsters aan dezelfde verbodsbepalingen gebonden zijn als de poronno en degenen, die getatoueerd worden. Speciale vermelding verdient nog dat de persoon van den poronno bij het ma'boea geen rol speelt. Zoo kan b.v. de poronno te Pewaneang en te Amballong nooit optreden als pongkaloe, potoeak of posiodang.

Het loon van den poronno is ons verschillend opgegeven. Te Lodang gaf men als loon op: gestampte rijst, een kip, koperen armbanden (saloerang) en foeja, of een stuk geweven goed (belatjoe). Te Wono krijgt de boronno van ieder, die zich laat tatoueeren, een koperen armband, en verder volop te eten. Ook de helpers en helpsters worden ruimschoots van voedsel voorzien tijdens de tatouage. Uit deze twee loonsopgaven zou wellicht de slotsom getrokken kunnen worden, dat de koperen armbanden het integreerende deel van de belooning vormen. Hierbij zij echter dadelijk gevoegd, dat men in Seko het kopergieten niet (niet meer?) kent.

Gaan wij vervolgens na, hoe de tatouage plaats heeft. Wanneer men wil gaan tatoueeren, vereenigen allen, die ermee te maken hebben, zich onder de rijstschuur van den tobara'. Te Wono heeft men te voren een buffel geslacht. Van alle deelen van het dier offert men een weinig aan de geesten onder de aarde en die van de hooge bergen. Men roept hen aan en vraagt om bijstand bij de tatouage. Iedereen, zoowel de poronno, zijn helpers en zij, die zich laten bewerken, als alle andere bewoners van het dorp, eet mee van dit vleesch. Het vleesch en de rijst worden gekookt in de dagelijks gebruikte gebakken aarden potten. 
Als instrument bij het tatoueeren gebruikt men een houten of ijzeren staafje, waaraan twee ijzeren naalden dicht bij en naast elkaar zijn vastgebonden. Zulk een instrumentje heet os oe. Met behulp van. het roet van damarhars (oro dama) teekent men de verlangde figuren op de huid. Hierop neemt men een mengsel van bovengenoemd roet met gal van de python (poerue saha) en een beetje water (dit mengsel noemt men peronno); in dit vocht doopt men de naalden van de osoe en prikt deze kleurstof langs de geteekende lijnen in de huid. $Z$ ijn op deze wijze alle figuren afgewerkt, dan wrijft men de huid af met een natten doek. De gedeelten, die nog onduidelijk blijken te zijn, worden overgedaan. Men zegt, dat de kleurstof zoo doordringt, dat czelfs de beenderen er zwart van worden.. In ieder geval waren de lijnen bij de oude vrouwen, wier tatouage ik nageteekend heb, nog zeer duidelijk zichtbaar. Wanneer de bewerker zijn werk goed en handig doet, verklaarden deze vrouwen, dan is de operatie niet zoo pijnlijk. Maar in ieder geval zetten de getatoueerde deelen na de bewerking op.

Bij de vrouwen worden alleen de armen en het schouderblad getatoueerd. De mannen mogen kiezen, of alleen de beenen van de enkels tot de knie, òf borst, buik, rug en hals (het bovenlijf dus). De armen mogen bij de mannen niet getatoueerd worden. Men zegt, dat een man, die zoowel onderbeenen als bovenlijf liet tatoueeren, so em poe zou worden, d.w.z. alles, wat hij ondernam. zou hem mislukken. Bij de eerste tatouage worden bij de vrouwen de onderarmen bewerkt: de eerste dag de buiten- en daarna de binnenkant van den rechter benedenarm, den tweeden dag de buiten- en binnenkant van den linker benedenarm. Bij de volgende gelegenheid, d.i. dus een jaar later, komen de bovenarmen aan de beurt. Dit geldt natuurlijk alleen voor Wono, daar men te Pewaneang en Amballong alles achter elkaar afwerkt.

Voor de mannen gaf men te Wono den volgenden regel. Worden alleen de onderbeenen getatoueerd, dan doet men eerst de vooren daarna de achterzijde. Verkiest iemand echter zijn bovenlijf te doen bewerken, dan wordt bij de eerste keer de rug getatoueerd, terwijl buik en borst met hals het volgende jaar aan de beurt komen. Deze regel gold echter voor Pawaneang en Amballong blijkbaar niet; want de eenige getatoueerde man, die in genoemde plaatsen nu nog te vinden is, heeft alleen een uitgebreide figuur op borst en schouders (zie Pl. II, $\mathrm{N}^{\circ}$ 6). Verder heeft men blijkbaar ook dikwijls voor de aardigheid een beetje 
getatoueerd. Zoo prijkt een man te Wono met een enkel figuurtje op de borst (zie Pl. II, $\mathrm{N}^{\circ}$. 5) en een figuur op den onderarm (zie Pl. II, No. 9), wat volgens den regel niet zou mogen. Ook het hoofd van Wono heeft een gefantaseerd teekeningetje op zijn onderarm, zelf er voor de aardigheid op gewerkt. Maar ik vermoed toch, dat de gegeven regels oorspronkelijk bindend voor allen geweest zijn.

Tijdens de tatouage zijn allen, die er bij betrokken zijn, aan verschillende verbodsbepalingen gebonden. Te Wono mogen zij de volgende spijzen niet eten: een varenkruid ( $t$ a mpaoe), colocasia (kalese) en alles wat zuur is. Deed men het toch, dan zouden de figuren niet houden, na korten tijd zou alles verdwenen zijn. Menstruatie noch zwangerschap is voor de tatouage eenige verhindering. Ook is de uitoefening van coïtus niet verboden. Zoolang de getatoueerde deelen nog gezwollen zijn, moet men die zorgvuldig bedekken, opdat niemand ze zie; wanneer een mede-getatoueerde het gezwollen lichaamsdeel zag, zou dit geen nadeelige gevolgen hebben, maar de blik van anderen zou maken, dat de zwelling toenam en de getatoueerde figuren verdwenen. Verder mogen zij met hun ontstoken lichaamsdeelen niet bij den rijstaanplant komen; vandaar dat, wanneer te Wono allen, nadat de twee tatouagedagen voorbij zijn, aan den nieuwen sawah gaan arbeiden, de pas getatoueerden er zich van verwijderd moeten houden, want anders zou de rijst mislukkken. Hetzelfde zou plaats hebben, wanneer men tatoueerde, terwijl de rijst nog te velde stond.

Ten slotte zij nog de volgende verbodsbepaling vermeld. Wanneer men den eersten dag bezig is met tatoueeren, en het gaat dan regenen, onweeren, er komt een regenboog, of iemand sterft in het dorp, dan moet men dadelijk met de bewerking ophouden, want deed men dit niet, dan zouden de getatoueerde deelen erg opzetten en de aangebrachte figuren zouden verdwijnen. Den volgenden dag zet men dan ongestoord de kunstbewerking voort. Deze bepaling geldt alleen voor den eersten dag; hebben bovengenoemde onheilspellende verschijnselen op den tweeden dag der tatouage plaats, dan stoort men er zich niet aan.

Bezien wij nu de figuren wat nader. Doordat men sinds een heel geslacht niet meer tatoueert, zijn op het oogenblik. alleen nog enkele ouden te vinden, die de figuren in hun huid vertoonen. Te Lodang en te Wono nam ik de figuren over van twee vrouwen 
P1. I.

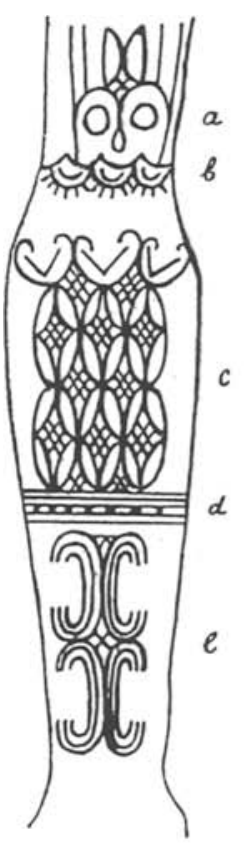

1.

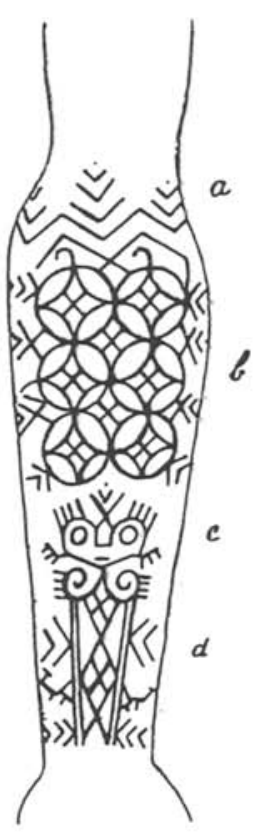

2.

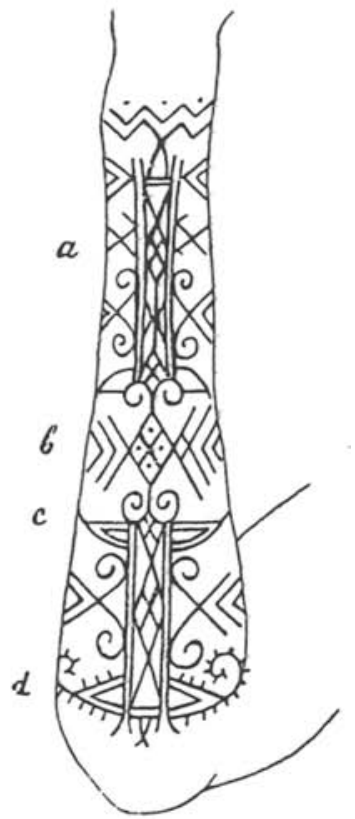

3.
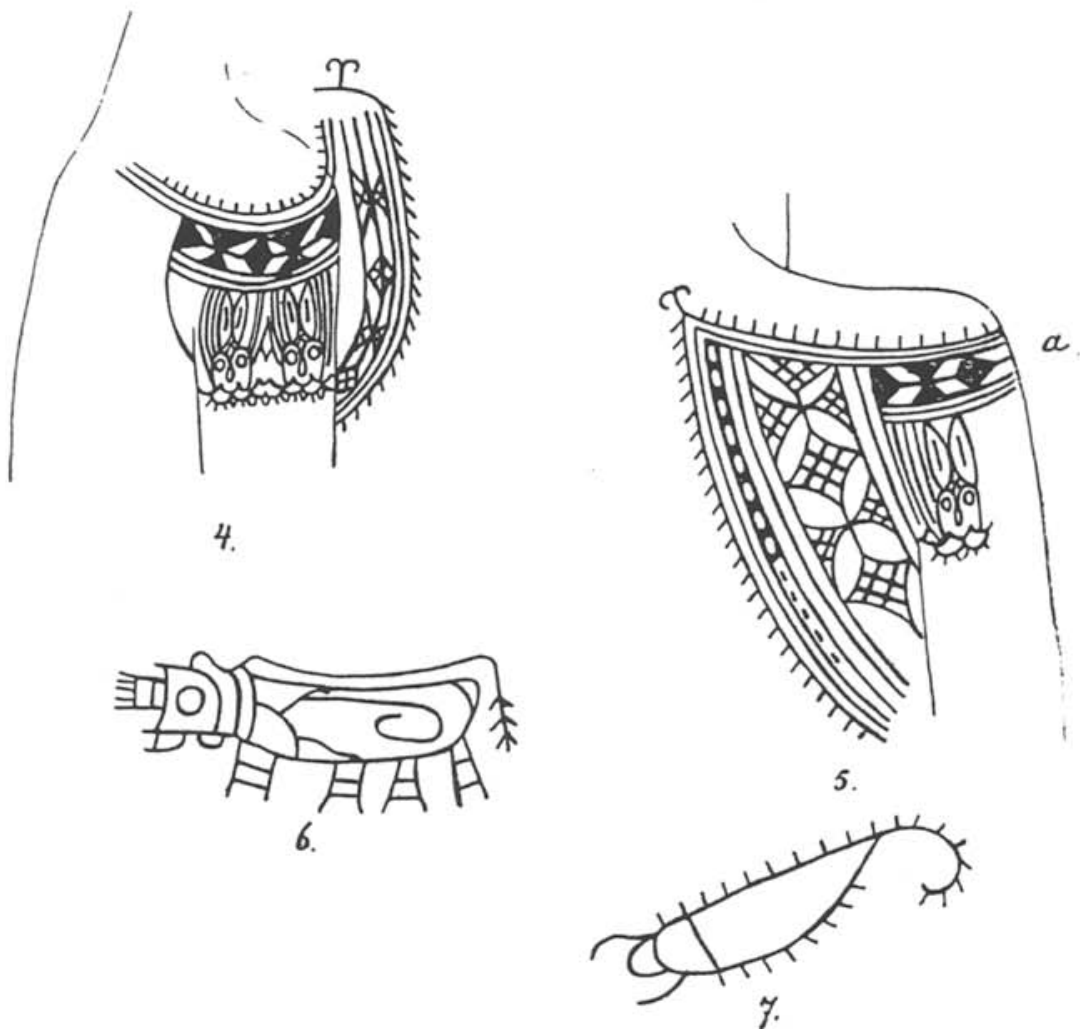

Fig. 1 en 2. binnenkant van een vrouwenarm. - Fig. 3. de buitenkant van een vrouwenarm. - Fig. 4. de schouder van een vrouw. - Fig. 5. het schouderblad van een

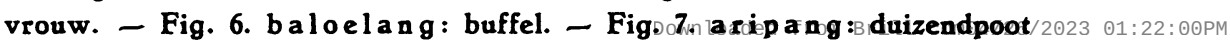


P1. II.

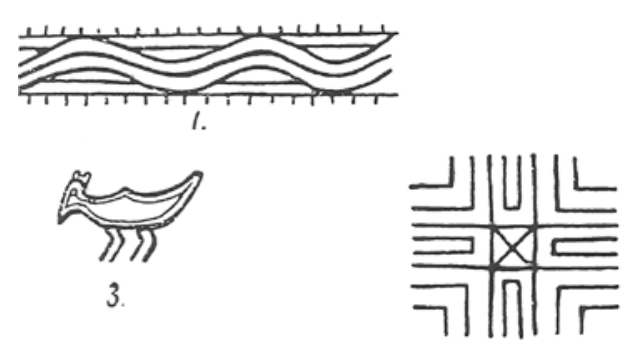

4.
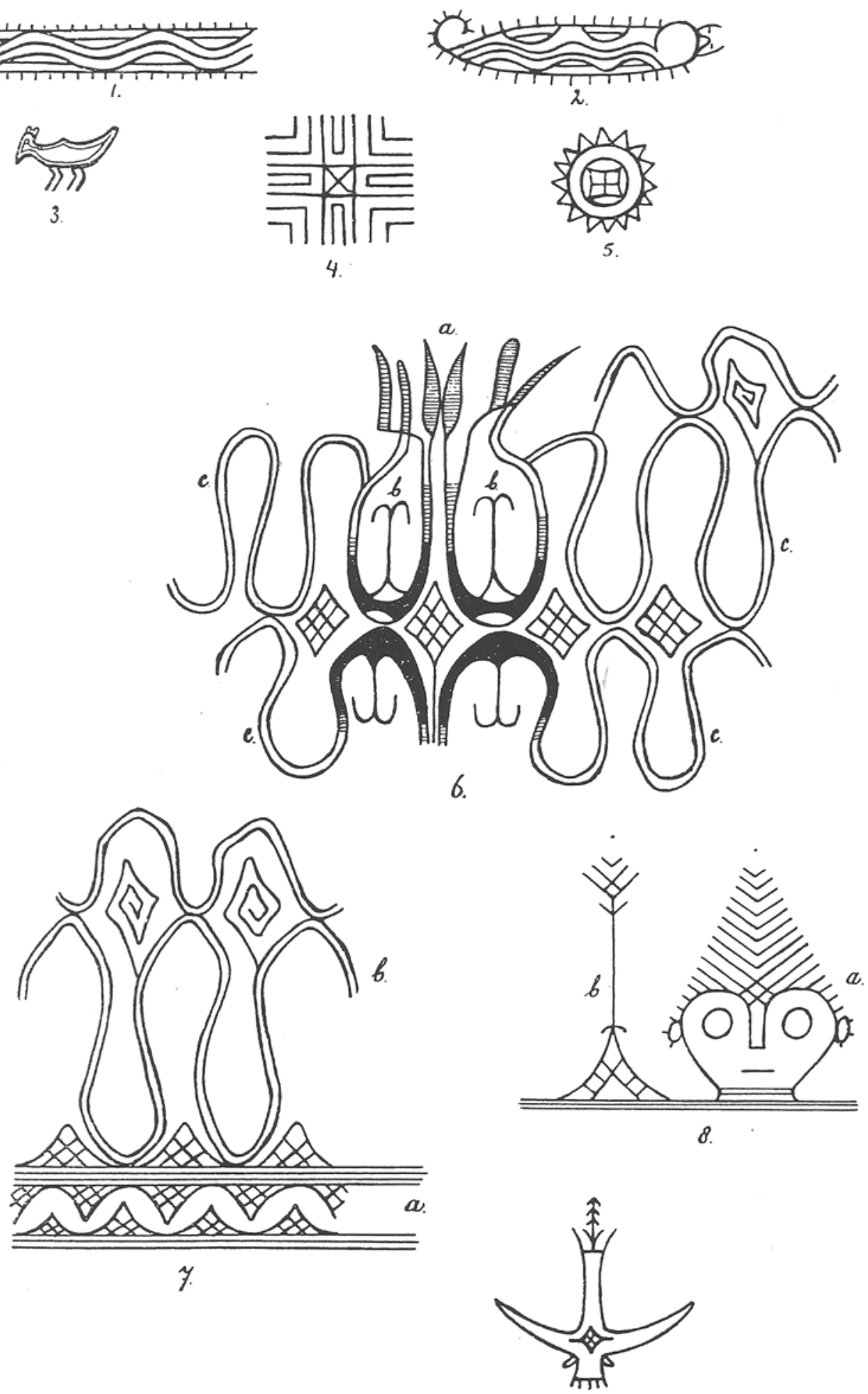

9.

Fig. 1 en 2. takale: groote armband. - Fig. 3. manoek: vogel. - Fig. 4. ronno lasa.

Fig. 5. soerede. - Fig. 6. t a' b o'. - Fig. 7. voortzetting van fig 6 6 op schoudef egn $01: 22: 00 \mathrm{PM}$ bovenarm. - Fig. 8. sila-sila met ala'na. - Fig. 9. tannoek: horens. via free access 
(Plaat I en Plaat II, $N^{\circ} 1,2,4$ en 8); in laatstgenoemde plaats prijkt een man met de figuren, die afgebeeld staan op Pl. II, $N^{\circ} 5$ en 9 ( 5 midden op het borstbeen en 9 op den buitenkant van den rechter onderarm), terwijl ik te Amballong gelegenheid had van de borst en schouders van een man van Pewaneang de figuren 6 en 7 van Pl. Il over te nemen.

Op Plaat I, fig. 1, staat de binnenkant van den onderarm van een vrouw afgebeeld. De fig. $a$ noemt inen sila-sila (sila: gezicht), en komt eenige malen in verschillenden vorm voor. De halve cirkels daaronder $(b)$ heeten seriria sipoe: hengsel van de betelzak. Dezelfde benaming geeft men aan de figuren $2 d, 3 a$ en de figuren op de borst van 4 . Verder zien wij op dezelfde figuur 1 het motief $c$, dat kapa-kapa genoemd wordt (kapa: katoen). Deze komt in een gewijzigden vorm maar onder denzelfden naam voor op figuur $5 a$, duidelijker nog te zien op figuur 4 . Beide vormen, nl. de eironde en de vierhoekige, worden gebruikt voor de tatouage van den bovenkant der handen. Wat op de plaat is angeduid met $d$ (fig. 1), noemt men saloengan, d.i. een kleine armband. De groote armband heet takale, waarmede men de figuren aanduidt, die op Pl. II, $\mathrm{N}^{\circ} 1$ en 2 zijn afgebeeld. Ten slotte bevat figuur 1 nog het motief $e$, dat den naam draagt van papoepapoe (papoe is een oneetbare varensoort). Met dezen naam worden ook aangeduid de teekeningen, die men bij de figuren 2 en 3 respectievelijk met $a$ en $b$ vermeld ziet.

Bij figuur 2 is alleen het motief pehong $(b)$ op te merken. Pehong is een cirkel, zooals men die op de huid afgedrukt vindt, wanneer men een loodrecht op de lengteas doorgesneden cylinder met het snijvlak op de huid drukt (b.v. een bamboekokertje). De heele complex van figuren op fig. 3, die duidelijk een eenheid vertoont, heet so eko. Dit woord duidt eigenlijk een lengtemaat aan, die gelijk is aan den afstand van elleboog tot vingertop. In de soeka' herhalen zich reeds genoemde figuren. Alleen zij de aandacht nog gevestigd op de tannoe' (horens) (c) en tanosoe (d). Tanosoe is een soort varen, die te Lodang hoela dang genoemd wordt.

Op figuur 4 is de beteekening van den vrouwenschouder afgebeeld terwijl fig. 5 het schouderblad van dezelfde persoon te zien geeft. Deze laatste versiering wordt ook genoemd abe' (Wono: schouderblad) of bose (Lodang: schouderblad). De overige figuren spreken voor zichzelf.

Dl. 76 
Van de teekeningen, die op Plaat II staan, meld ik nog de volgende bijzonderheden. De naam soerede (fig. 5) duidt een grassoort aan. In de teekening van fig. 6 noemt men het motief $a$ papetiha wat op tiha lijkt. Tiha is de jonge stam van de pisang, die men aan dunne schijfjes snijdt en als groente kookt. Papesaikang noemt men de figuur $b$; want saikang is een haak, waaraan men iets ophangt. In de slingers, die het voornaamste van de geheele teekening uitmaken, ziet men een touw; vandaar de naam toe'oe-toe'oe, want toe'oe is een knoop, zooals men die in een touw legt. Het geheel noemt men eenvoudig ta'bo', dat het Pewaneangsch is voor het Wono woord ronno: teekening. Men moet zich bij deze figuur voorstellen, dat $a$ getatoueerd is op het benedengedeelte van den hals, terwijl de volle teekening de borst bedekt, en figuur 7 de schouders versiert. Hierbij loopt $a$ als een band om den bovenarm en ligt $b$, die een voortzetting van $c$ in fig. 6 is, op de schouders. Van figuur 8 valt alleen nog te vermelden, dat $b$ a la'n a heet, dat zooveel als tusschenfiguur zou moeten beteekenen.

Een bepaalde beteekenis hecht men aan geen der teekeningen. Te Lodang beweerde men, dat de figuren pehong en aripang (Plaat I, fig. $2 b$ en fig. 7; a ripang beteekent: duizendpoot) getatoueerd moesten worden, terwijl men in de overige figuren geheel vrijwas. Te Wono vertelde men ons, dat, wanneer men bij een vrouw (ex-haliang) met tatoueeren wilde beginnen, men het allereerst de figuur ron no lasa (Pl. II, fig. 4) aanbracht op den buitenkant van den arm bij den elleboog. Daarna ging men over tot de soeka'.

Op de vraag of de leden van alle drie de standen getatoueerd mochten worden, gaf men te Lodang ten antwoord, dat de ka oen an uitgesloten waren, dus alleen de tobara' en de todirenge tot de tatouage worden toegelaten. Te Wono antwoordde men, dat allen zich aan de bewerking mochten onderwerpen, maar dat er toch groot verschil bestond. Want de $\mathrm{k}$ a o e $\mathrm{nan}$ mochten alleen de figuur ronno lasa dragen. De todirenge behalve deze figuur ook nog de pehong en de manoek (Plaat II, fig. 3) ${ }^{1}$ terwijl de tobara' met alle motieven getatoueerd werden.

1 Geen van de getatoueerde personen, die wij gezien hebben, vertoonde deze figuur manoek. In het houtsnijwerk, waarin de To Seko een groote vaardigheid bezitten, komt dit motief zeer veelvuldig voor. Men verklaarde ons, dat precies dezelfde figuur bï de tautoage gebruikt werd, wat wel aan te nemen is. Darom heb ik deze manoek onder de figuren opgenomen. 
Zooals reeds gezegd is tatoueert men in Seko niet meer. Als reden geeft men op, dat men de figuren niet meer geheel juist weet te maken. Alle moeite en ellende van den laatsten tijd wijt men daaraan, dat de teekeningen niet meer aan de overgeleverde eischen voldoen. Daarom zegt men: «Beter heelemaal niet dan verkeerd.

Omtrent de herkomst van de tatouage weet men heel weinig te vertellen. Te Wono zegt men deze gewoonte van de lieden van. Pewaneang en Amballong gekregen te hebben. Dezen hebben het weer geleerd van een zekeren Talamia, die de eerste bewoner van Pewaneang moet zijn geweest. Maar vanwaar deze Talamia afkomstig is, of hij uit den hemel of uit de aarde, uit steen of uit water, uit een bamboe of uit een boom is voortgekomen weet men niet. Alleen vertelt men dat hij een reus was. De steen, waarmede hij gewend was zijn mes te wetten, kan men nu nog aanwijzen, en deze is zoo groot, dat dertig man hem nog niet van den grond kunnen tillen.

Op de vraag, of Talamia wellicht ook iets te maken had met den watergeest, die hun het ma'boea geleerd had, antwoordde men, dat zij niets met elkaar uitstaande hadden. Toen men het ma'boea en de tatouage beide geleerd had, heeft men ze samen verbonden.

Vestigen wij voor een oogenblik de aandacht op twee voorloopig nog niet op te lossen vragen. In de eerste plaats is het verband tusschen de boea en de tatouage niet duidelijk. De legende zou er op wijzen, dat het verband zeer los moet zijn, want degenen, die de beide gebruiken brachten, hebben niets met elkaar uit te staan. Uit de boven vermelde gegevens valt echter wel de slotsom te trekken, dat het haliangschap en de tatouage wel nauw verbonden zijn. Want van de haliang wordt gezegd, dat ze verplicht is zich te laten tatoueeren, terwijl het voor anderen facultatief is.

Voordat men tot eenige zekerheid hieromtrent kan komen, zouden eerst uitgebreider onderzoekingen gedaan moeten worden, opdat èn van de To Seko zelf, è van de omwonende volken meer bekend worde. Op het oogenblik ontbreekt ons te zeer het materiaal tot vergelijking. Van onzen tolk, den wegopziener P. Kare, die van Makale afkomstig is, kregen wij eenige zeer onvolledige gegevens omtrent de tatouage in zijn vaderland. Deze mededeelingen laat ik hier in het kort volgen als zijnde 
het eenige materiaal voor vergelijking, dat ons thans ten dienste staat.

In het Makalesche n.l. heeft vroeger ook de tatouage bestaan, maar sinds eenige geslachten wordt deze kunst niet meer beoefend. Waar het nu voor ons op het oogenblik op aankomt is het volgende: men tatoueerde in Makale vroeger, wanneer men een heel voordeelig jaar gehad had, wanneer de rijst goed gelukt was, en menschen en karbouwen niet door ziekte en dood waren bezocht. In drie jaren was de tatouage voltooid, in welken tijd de toembangs (de haliangs van Seko), die uitsluitend uit vrouwen (meisjes) bestaan, aan allerlei verbodsbepalingen gebonden zijn. $\mathrm{Zij}$ moeten n.l. altijd in het geel gekleed zijn, mogen alleen rijstemeel met buffelmelk gemengd eten, mitsgaders bailo, een soort pisang (barangan) en offervleesch voor de goden (geen offervleesch voor de dooden). Als er een vorst sterft, houden alle verbodsbepalingen op en gaat dus de tatouage niet door. Deze drie jaren van verbodsbepalingen en tatouage worden afgesloten door plechtigheden en feesten.

De eerste drie dagen heeft het soemongolo' plaats, waarbij de toembangs in een waringin mueten wonen. Ze worden er heen gedragen, want ze mogen den grond niet raken. Een mooie trap voert naar boven, waar aan elke sport twee gouden krissen zijn gebonden, terwijl twee zwaarden van manoeroeng (iemand, die uit den hemel is gedaald) er bij gezet worden. De plaats, waar de toembangs zitten, wordt afgezet met mawa, een soort weefsel, terwijl aan den buitenkant van dit afschutsel eenige konaoe-bladeren (Arenga saccharifera) worden gehangen.

$\mathrm{Na}$ deze drie dagen heeft een feest plaats in de vlakte, waar een hut (lake-lakean) voor de toembangs wordt opgericht, benevens hutten voor de feestvierenden. De to e mbang mogen nog steeds niet den grond aanraken. $\mathrm{Ze}$ worden met een stuk mawa overdekt, en aldus drie malen om de lake-lakean gedragen van rechts naar links. Degenen, die de tatouage-aangelegenheden geregeld hebben, zijn de woerake, een vrouw, en de sando tomenani, een man. De eerste speelt bij de ommegangen om de lake-lakean op de garapoeng (kleine trommeltjes) de tweede rinkelt met de ma'bangkoela (belletjes). Drie dagen blijven de to e mbangs in hun huisje, waarop ze er uit mogen en den grond weer mogen betreden. Hierbij 
heeft een groot feest plaats. De getatoueerden heeten dan toemba', toemba' sapeng, hetgeen een eerenaam is.

Deze gegevens, die zeer onvolledig zijn en aan de noodige nauwkeurigheid nog veel te wenschen overlaten, wijzen $\mathrm{m}$. i. reeds de richting aan, waarin mogelijk de verklaring en de geschiedenis van de boea en de tatouage gezocht moeten worden. Het is om de aandacht op eenige dingen te vestigen, dat ik hier een enkele veronderstelling doe volgen. Wellicht staat de tatouage en wat daaraan vast $z$ it in verband met den rijstbouw, en bedoelt men het als een dankoffer aan den heer van de rijst, die buven woont. ${ }^{1}$ Eenige trekken in hetgeen hierboven omtrent de tatouage in Makale gezegd is, kunnen hierop wijzen. Wij gaan hier nu niet op in; wellicht dat er later gelegenheid zal zijn iets anders en zekerders hieromtrent mede te deelen.

In Seko heeft men dan waarschijnlijk twee verschillende gebruiken, die punten van overeenkomst hadden, met elkaar versmolten. Men had een feest, dat $\mathrm{ma}$ 'boea heette, en dat tot doel had het klaarblijkelijk tekort aan levenskracht in den stam te vermeerderen, waarop zeer sterk de $\mathrm{tandas}$ ang te Pewaneang en Amballong wijst. Want wanneer de rijst steeds mislukte en bovendien mensch en dier ziek werden en stierven, was dit een duidelijk bewijs daarvoor, dat men behoefte had aan aanvulling van levenskrachten. Bij deze $\mathrm{ma}$ 'boea-plechtigheden werden ook wellicht eenige of vele meisjes tijdelijk van de buitenwereld afgesloten, welke afsluiting dan slechts enkele dagen duurde, zooals bij de haliangs te Pewaneang en Amballong (wellicht zou hier bij nader onderzoek een parallel te trekken zijn met het momparilangka of pakawoerake bij de Bare'e Toradja's; zie Adriani en Kruyt, Bare'e-sprekende Toradja's I, blz. 364 e.v. v.).

Hiernaast had men de tatouage, die als een dankoffer voor den genoten voorspoed gold. Ook hierbij werden meisjes, die bestemd waren om de kunstbewerking te ondergaan, een korter of langer tijd van de buitenwereld afgesloten. Waardoor men misschien tot de gedachte is gekomen om de meisjes, die voor het $\mathrm{ma}$ 'boea reeds afgezonderd werden, tegelijkertijd de rol te laten spelen van de toe mbang in Makale.

Zoo dit juist is, zou men kunnen zeggen, dat Pewaneang en

1 Zie voor het verband, dat er bestaat tusschen rijst., speciaal sawahbouw, en hemelingen het boek van W. J. Perry, The Megalithic Culture of Indonesia, Manchester 1918. 
Amballong de gedachte van de boea, versterking van de levenskracht, het sterkst hebben vastgehouden; terwijl men te Wono sterker het tatouage-idee heeft opgenomen. Dit zou des te eigenaardiger zijn, wanneer men in aanmerking neemt, dat de menschen van Wono zeggen, dat Talamia, die het tatouage-gebruik heeft gebracht, de stichter van Pewaneang is geweest, vanwaar de lieden van Wono het hebben overgenomen. Maar, znoals bekend, komt het meermalen voor dat een gebruik beter is bewaard gebleven in een streek, waarheen het overgegaan is, dan waar het vandaan gekomen is. $W_{i j}$ zullen hier echter niet langer bij stil staan, omdat hier vele mogelijkheden zijn, en nog niets met zekerheid te zeggen valt.

Ten nauwste met deze vraag is de kwestie verbonden, in hoeverre wij bij deze gebruiken met een oorspronkelijke («primitieve») cultuur te maken hebben. Het lijkt mij goed bij het onderzoek hiernaar steeds het woord van Ratzel in gedachte te houden: "Die Ethnographie zeigt nicht die Völker in ihren natürlichen, sondern in ihren geschichtlichen Beziehungen.» (Anthropogeographie II, $2^{\text {e }}$ druk blz. 394, $1^{\text {e }}$ druk blz. 606). Dat dit ook voor Seko geldt is op het eerste gezicht duidelijk, maar de mogelijkheid is niet uitgesloten, dat in deze vergeten uithoek twee of meer culturen meer naast elkaar zijn overgenomen, dan dat er van een opnemen en eigen verwerking van vreemde elementen sprake is. Dit doet de onbeholpen wijze, waarop èn in de legende èn in de practische uitvoering de tatouage aan de boe a verbonden is, sterk vermoeden. Ook bij onze andere onderzoekingen bij dit volk bleek telkens, dat deze menschen wel veel hebben overgenomen, maar weinig zelf verwerkt: meer nagedaan dan tot hun eigendom gemaakt. Laat ik hiervan een voorbeeld mogen noemen.

Op onze vraag, welke beteekenis men nu in Seko aan de tatouage hecht, bleek het antwoord kortweg te zijn: geen beteekenis. Noch bij de lijkbezorging, noch in het dagelijksch leven maakt men eenig verschil tusschen getatoueerden en niet-getatoueerden. In het hiernamaals bestaat er tusschen hen ook geen verschil. De gewezen haliangs, die dus ook allen getatoueerd zijn, onderscheiden zich in niets van de overige vrouwen, in tegenstelling met de toemba'sapeng in Makale. Het is dus duidelijk, dat men er absoluut geen vermoeden meer van heeft, waartoe men zich heeft laten tatoueeren; de beteekenis van deze 
gewoonte hangt voor hen geheel in de lucht, noch gesteund door eenige overlevering, noch door een zelf erbij gedachte bedoeling. Bij een dergelijk volk mogen wij verwachten, dat zich twee processen in zijn geschiedenis naast elkaar hebben afgewikkeld: aan den eenen kant een overnemen van een hoogere cultuur dan het op een gegeven oogenblik zelf bezat, en aan den anderen kant een ontbinding van de geestelijke en stoffelijke cultuur, die het reeds eigen was. 